\title{
A METHOD FOR OPTIMIZING CHEMICAL COMPOSITION OF STEELS TO REDUCE RADICALLY THEIR ALLOY ELEMENTS AND INCREASE SERVICE LIFE OF MACHINE COMPONENTS
}

Nikolai Kobasko

Intensive Technologies Ltd

68/1 Peremohy ave., Kyiv, Ukraine, 03113

nkobasko@gmail.com

\begin{abstract}
A method for optimizing chemical composition of steel is proposed and a correlation is established to reduce cardinally alloy elements in existing steel grades that results in high compressive residual stresses at the surface of intensively quenched steel parts and increasing strength and ductility of material due to super-strengthening phenomenon. The algorithm of optimization consists in reducing alloy elements in existing alloy steel in 1.5-2 times and then lowering step-by-step content of steel, beginning from the most costly alloy element and ending the most cheaper one, until established correlation is satisfied. The range of reduction is minimal and during computer calculations can be chosen as $0,001 \mathrm{wt} \%$. The proposed approach can save alloy elements, energy, increase service life of machine components and improve environmental condition. The method is a basis for development of the new low hardenability $(\mathrm{LH})$ and optimal hardenability $(\mathrm{OH})$ steels.
\end{abstract}

Keywords: steel chemistry, service life, reduced cost, carburizing elimination, natural gas savings.

\section{Introduction}

Author of the article has been developing a method for optimization of steel chemistry to reduce radically alloy elements, increase service of steel components and improve environment condition since 2005 [1-3]. In this article a summary of the investigations concerning optimization of chemical composition of steels is provided. Based on numerous experiments and FEM calculations of residual stresses, it was established a dimensionless correlation which is responsible for creation of optimal hardened layer that provides high compressive residual stresses at the surface of steel parts and allows getting super-strengthened material. For this purpose the Grossmann's classical experimental data were used concerning hardenability of steels and multiplying factors $f_{n}$ which are the most accurate and widely used $[4,5]$.

The aim of developed method is providing methodology which allows engineers to develop the new low hardenability (LH) steels for elimination very costly carburizing processes. At present, in worldwide practice there is a tendency to switch from AISI 8620 carburized alloy steel to LH steel which should be intensively hardened in plain water. The matter is that carburizing process for big and complicated steel parts, like large gears, takes a long time, up to 60 hours and is rather costly and not environmental green. The LH steel with the proper optimal chemical composition can eliminate carburizing process completely and it takes only seconds or minutes for intensive hardening. The proposed method for optimizing chemical composition of LH steels can be successfully used for solving this very important for the worldwide practical and scientific problem.

2. Compressive residual stresses and super-strengthening phenomenon as a reason for cardinal decrease alloy elements in steels

Optimal hardenability of steels which provides optimal hardened martensitic surface layer with maximal compressive residual stresses in it and bainitic or pearlitic microstructure at the core after intensive quenching can be designed using established by author [1,2] the similarity ratio (1):

$$
\frac{\mathrm{DI}}{\mathrm{D}_{\mathrm{opt}}}=0.35 \pm 0.095
$$

here $\mathrm{DI}$ is critical diameter in $\mathrm{m} ; \mathrm{D}_{\text {opt }}$ is diameter of steel part to be quenched in $\mathrm{m}$. 
A procedure of its use is as follows:

1. A steel grade with certain chemical composition is chosen.

2. The ideal critical size for this steel is determined.

3. The ratio $\mathrm{DI} / \mathrm{D}_{\text {opt }}$ for specific steel part is evaluated which must be in the range of $0.2-0.5$.

4. The part is quenched in condition $0.8 \leq \mathrm{Kn} \leq 1[6]$.

5. Intensive quenching is interrupted when optimal quenched layer is achieved with maximal compressive stresses at the surface [6].

6. The part is tempered at the temperature Ms or higher [6].

The history of such development started when Prof. Shepelyakovskii and his colleagues noticed that not through hardened but intensively quenched steel parts has much better service life as compared with through hardened steel parts [7-11]. As a result, steels with reduced content of $\mathrm{Mn}, \mathrm{Cr}$ and $\mathrm{Ni}$ were recommended to use to increase service life of machine components (Table 1).

\section{Table 1}

Chemical composition of steels with reduced content of Mn recommended by Prof. Shepelyakovskii to use for through surface induction hardening of different machine components [10]

\begin{tabular}{ccccccc}
\hline Alloy & Steel 1 & Steel 2 & Steel 3 & Steel 4 & Steel 5 & Steel 6 \\
\hline $\mathrm{C}$ & $0.55-0.63$ & $0.44-0.51$ & $0.95-1.05$ & $0.42-0.48$ & $0.53-0.60$ & $1.10-1.20$ \\
$\mathrm{Si}$ & $0.10-0.30$ & $0.10-0.25$ & $0.15-0.30$ & $0.40-0.65$ & $0.40-0.80$ & $0.15-0.30$ \\
$\mathrm{Mn}$ & $<0.20$ & $0.95-1.25$ & $0.15-0.30$ & $0.17-0.32$ & $0.21-0.35$ & $0.40-0.60$ \\
$\mathrm{Cr}$ & $<0.15$ & $<0.25$ & $0.35-0.50$ & $<0.25$ & $<0.25$ & $<0.25$ \\
$\mathrm{Ni}$ & $<0.25$ & $<0.25$ & $<0.30$ & $<0.20$ & $<0.20$ & $<0.20$ \\
$\mathrm{Cu}$ & $<0.30$ & $<0.30$ & $<0.25$ & $<0.15$ & $<0.20$ & $<0.20$ \\
$\mathrm{Ti}$ & 0 & $0.06-0.12$ & 0 & 0 & 0 & $0.06-0.12$ \\
$\mathrm{~S}$ & $<0.04$ & $>0.04$ & $<0.027$ & $<0.04$ & $<0.04$ & $<0.04$ \\
$\mathrm{P}$ & $<0.04$ & $>0.04$ & $<0.02$ & $<0.035$ & $<0.04$ & $<0.04$ \\
& & & & & Hard working \\
Area of use & Gears & Semi-axles and & Leaf - springs & Common & Crank - shafts & parts
\end{tabular}

To understand why such phenomenon occurs, authors [12-16] made numerous computer simulations to investigate current and residual stresses in cylindrical samples of $6,20,40,50$, $60,80,150,200$, and $300 \mathrm{~mm}$. It was established that there is a similarity in stress distribution as shown in Fig. 1. The similarity means that a depth of optimal quenched layer should increase 10 times when switching from $6 \mathrm{~mm}$ cylindrical specimen to $60 \mathrm{~mm}$ specimen to get the same stress distribution. More information one can find in Refs. [17-22].

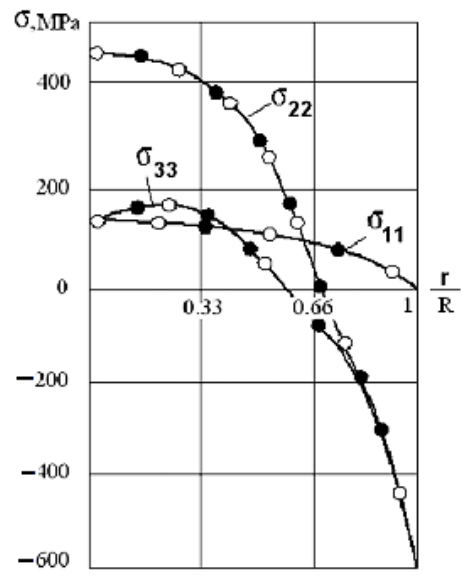

Fig. 1. Stress distribution through the section of two cylindrical specimens, one of diameter $6 \mathrm{~mm}$ (black data points) and the other of $60 \mathrm{~mm}$ (white data points), at the time of the achievement of maximum compressive stresses at the surface [12]: $\sigma_{11}$ is radial stress; $\sigma_{22}$ is axial stress,

$$
\sigma_{33} \text { is tangential (hoop) stress }
$$


The established in 1983 [12] similarity in stress distribution has a great importance since it allows:

- transfer data, obtained from testing small specimens, to very large specimens or real steel parts;

- get similar stress distribution and hardened layer in complicated steel parts;

- create a basis for optimization of the chemical composition of steel to provide high compressive residual stresses at the surface of hardened steel parts;

- use previously experimental data to evaluate the ratio (1);

- make appropriate condition to get maximal benefit from super-strengthening processes.

The similar stress distribution when quenching through hardened cylindrical specimens in oil (Fig. 2, a) and intensively quenched specimens with optimal hardened layer (Fig. 2, b) are shown in Fig. 2. A scheme (Fig. 3) explains how one should understand the super-strengthening processes [23-25].

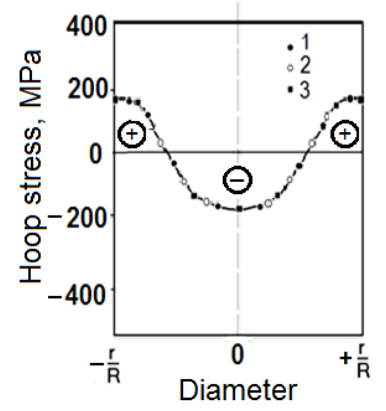

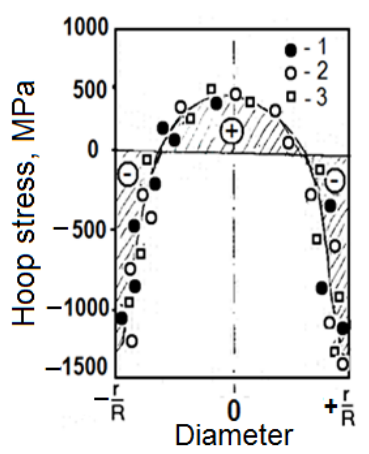

$b$

Fig. 2. Residual stress distribution in cylindrical specimens when quenching slowly in oil and intensively in water flow: $a$ - quenching in oil; $b$ - intensive quenching in condition $0.8 \leq \mathrm{Kn} \leq 1$

Thus, along with the creation the surface compressive residual stresses, intensive quenching is a reason for super-strengthening of material (Fig. 3, 4) [24, 26].

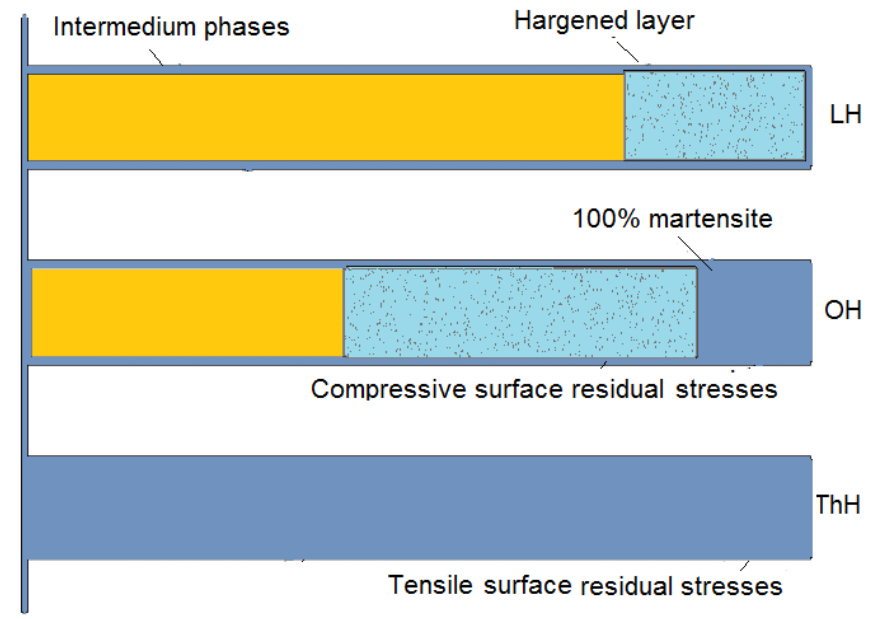

Fig. 3. Optimal depth of hardened layer corresponding to the maximum surface compressive residual stresses: LH, low hardenability steel; $\mathrm{OH}$, optimal hardenability;

ThH, through hardening

To understand the nature of super-strengthening, consider the scheme shown in Fig. 4. Imagine a superficial layer compressed to the limit (1,200-1,500 $\mathrm{MPa})$ in which there are plates of martensite possessing a greater specific volume than the initial phase structure of supercooled austenite. The period of appearance of such plates is very short and less than $10^{-6} \mathrm{~s}$. The plates of 
martensite deform the supercooled austenite that is between them, as shown in Fig. 4. The hatched area indicates martensite, and the color area, the supercooled austenite. The higher the cooling rate is within the martensite range, the greater will be the extent to which the austenite is deformed, and the higher the dislocation density. Consequently, during rapid cooling, there is not enough time for the dislocations to accumulate in the grain boundaries and to form nuclei of future microcracks; they are frozen in the material. Thus, the superficial layer acts like a blacksmith: under conditions of high stress, the plates of martensite arise explosively, deforming the austenite and creating extremely high dislocation densities, which are frozen during rapid cooling. This process is analogous to low-temperature thermomechanical treatment (LTMT).

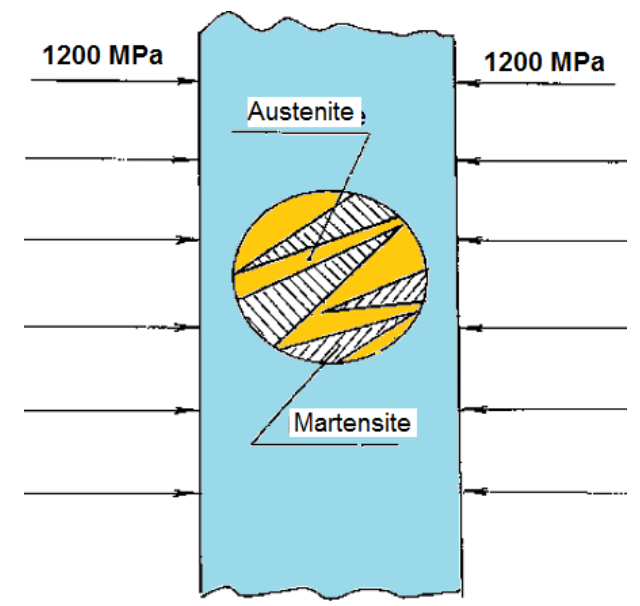

Fig. 4. The transformation scheme of austenite into martensite in the compressed layer, illustrating the effect of additional strengthening (super-strengthening) of the material

\section{Verification of the idea in the production conditions}

Author of a monograph published in 1980 [25] provided experimental data showing that semi-axles of track KrAZ (62 mm in diameter) made of plain carbon steel and intensively quenched work much better as compared with the axles made of AISI 4340 steel but quenched in oil (Table 2, 3 and Fig. 5).

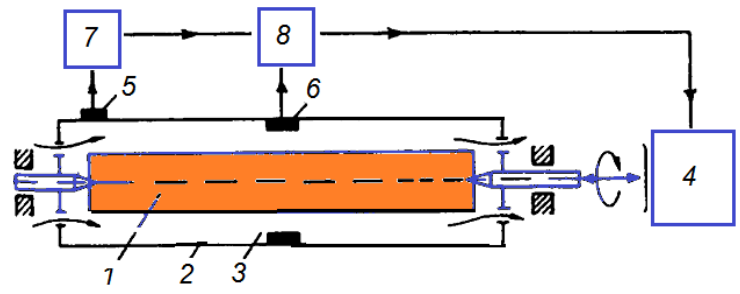

Fig. 5. Detailed scheme of quench chamber with automatic control [14, 28]: 1 - semi-axle; 2 - quench chamber; 3 - pressurized water flow; 4 - mechanical drive for semi-axles; 5 - sensor for analyzing the process of nucleate and film boiling; 6 - sensor for analyzing the portion of transformed structures by the changing ferromagnetic state;

7 - electronic device (amplifier and microprocessor); 8 - amplifier

Table 2

Chemical composition of steels AISI 4340H and 1040 used for manufacturing KrAZ track's semi-axles [27]

\begin{tabular}{cccccccccc}
\hline Steel grade & $\mathbf{C}$ & $\mathbf{M n}$ & $\mathbf{S i}$ & $\mathbf{N i}$ & $\mathbf{C r}$ & $\mathbf{M o}$ & $\mathbf{P}$ & $\mathbf{S}$ & $\mathbf{D I}, \mathbf{m m}$ \\
\hline AISI 4340H & $0.37-0.44$ & $0.65-0.85$ & $0.15-0.35$ & $1,65-2.00$ & $0.65-0.95$ & $0.20-0.30$ & $0.025 \max$ & $0.040 \max$ & $131-269$ \\
1040 & $0.36-0.44$ & $0.50-0.80$ & $0.17-0.37$ & $0.25 \mathrm{max}$ & $0.25 \mathrm{max}$ & - & $0.04 \max$ & $0.04 \max$ & $24-41$
\end{tabular}


Table 3

Fatigue testing of KrAZ tracks semi-axles through quenched in oil $(4340 \mathrm{H}$ steel) and intensively quenched for obtaining optimal quenched layer (1040 steel) [24-26]

\begin{tabular}{cccc}
\hline Quenching method & Steel grade & Numbers of cycles to fracture & Notes \\
\hline Oil & AISI/SAE 4340 & $(3,8-4.6) \times 10^{5}$ & Semi-axles were destroyed \\
$\begin{array}{c}\text { Intensive water } \\
\text { spray cooling }\end{array}$ & AISI 1040 & $(3,0-3.5) \times 10^{6}$ & No fracture observed
\end{tabular}

For plain carbon steel 1040 the main ratio (1) is equal:

$$
\frac{\mathrm{DI}}{\mathrm{D}_{\mathrm{opt}}}=\frac{24 \mathrm{~mm}}{62 \mathrm{~mm}}=0.35+0.037
$$

that perfectly fits the Eq. (1). Field testing showed that wear resistance of splines were three times higher as compared with 4340 steel. Note that plain carbon steel didn't contain Al, Ti and V.

Other good examples are rollers made of $35 \mathrm{KhM}$ steel (Table 4 and Fig. 6)

Table 4

Chemical composition of steel $35 \mathrm{KhM}$ used for manufacturing rollers

\begin{tabular}{cccccccccc}
\hline Steel grade & $\mathbf{C}$ & Mn & Si & Cr & Ni & Mo & P & S & DI mm \\
\hline $35 \mathrm{KhM}$ & $0.30-0.37$ & $0.50-0.90$ & $0.90-1.20$ & $0.90-1.20$ & $0.30 \max$ & $0.15-0.25$ & $0.035 \max$ & $0.035 \max$ & $89-222$ \\
Average & 0.335 & 0.70 & 1.05 & 1.05 & 0.15 & 0.20 & - & - & 153
\end{tabular}

Critical diameters in Table 2, 3 were calculated using Grossmann's Eq. (2) [4, 28, 29]:

$$
\mathrm{DI}=25.4 \mathrm{f}_{\mathrm{Fe}} \times \mathrm{f}_{\mathrm{Mn}} \times \mathrm{f}_{\mathrm{Si}} \times \mathrm{f}_{\mathrm{Cr}} \times \mathrm{f}_{\mathrm{Ni}} \times \mathrm{f}_{\mathrm{Mo}} \times \mathrm{f}_{\mathrm{P}} \times \mathrm{f}_{\mathrm{S}},
$$

here $\mathrm{f}_{\mathrm{Fe}}, \mathrm{f}_{\mathrm{Mn}}, \mathrm{f}_{\mathrm{Si}}, \mathrm{f}_{\mathrm{Cr}} \ldots$ are multiplying Grossmann's values depending on content of alloy in steel. Average critical diameter is $153 \mathrm{~mm}$ and ratio (1) is satisfied for large diameter of roller, i. e.

$$
\begin{gathered}
\frac{\mathrm{DI}}{\mathrm{D}_{\mathrm{opt}}}=\frac{153 \mathrm{~mm}}{600 \mathrm{~mm}}=0.255=0.35-0.095 ; \\
\frac{\mathrm{DI}}{\mathrm{D}_{\mathrm{opt}}}=\frac{153 \mathrm{~mm}}{280 \mathrm{~mm}}=0.54=0.35+0.19 .
\end{gathered}
$$

To provide direct convection, heat transfer coefficients (HTCs) were calculated using Eq. (3) and Eq. (4) according to which $\mathrm{HTC}=1250 \mathrm{~W} / \mathrm{m}^{2} \mathrm{~K}$. It can be provided by agitation water salt solution of optimal concentration with $0.25 \mathrm{~m} / \mathrm{s}$.

According to patented technology [6], direct convection and uniform intensive quenching takes place when criterion (3) including (4) is satisfied:

$$
\begin{gathered}
\mathrm{Bi}=\frac{2\left(\vartheta_{0}-\vartheta_{\mathrm{I}}\right)}{\vartheta_{\mathrm{I}}+\vartheta_{\mathrm{uh}}}, \\
\vartheta_{\mathrm{I}}=\frac{1}{\beta}\left[\frac{2 \lambda\left(\vartheta_{0}-\vartheta_{\mathrm{I}}\right)}{\mathrm{R}}\right]^{0.3},
\end{gathered}
$$


where $\vartheta_{0}=T_{0}-T_{S} ; T_{0}$ is initial austenitizing temperature; $\vartheta_{\mathrm{I}}=T_{\mathrm{I}}-\mathrm{T}_{\mathrm{S}}, \mathrm{T}_{\mathrm{I}}$ is nucleate boiling start temperature; $\mathrm{T}_{\mathrm{S}}$ is saturation temperature; $\vartheta_{\mathrm{uh}}=\mathrm{T}_{\mathrm{S}}-\mathrm{T}_{\mathrm{m}} ; \mathrm{T}_{\mathrm{m}}$ is bath temperature; $\beta=3.41$; $\lambda$ is thermal conductivity of steel in $\mathrm{W} / \mathrm{mK}$; $\mathrm{R}$ is radius in $\mathrm{m}$; $\mathrm{Bi}$ is conventional dimensionless Biot number.

Taken into account such approach, software has been developed for engineers to calculate cooling recipes when performing IQ-2 and IQ-3 processes [30-34]. The possibilities of governing the quenching processes are discusses in Refs [35-38].

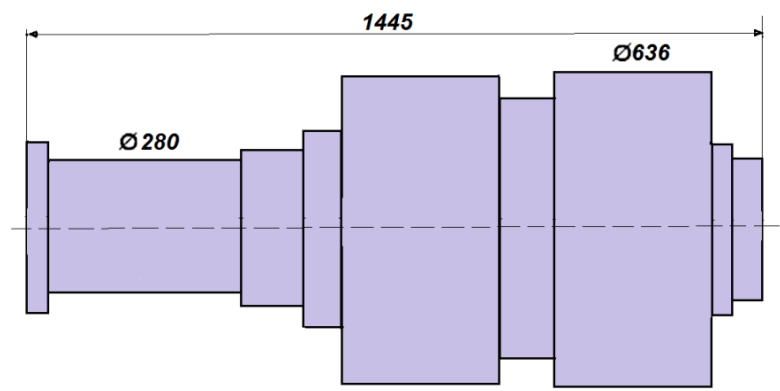

Fig. 6. The roller made of $35 \mathrm{KhM}$ steel and intensively quenched in agitated $(0.3 \mathrm{~m} / \mathrm{s})$ water salt solution of optimal concentration

Cooling time of roller shown in Fig. 6 was calculated using Eq. (5) [25] and existing computer program:

$$
\frac{\mathrm{aKn}}{\mathrm{K}} \tau=\left(\frac{\mathrm{k}_{1} \mathrm{Bi}_{\mathrm{v}}}{2.095+3.873 \mathrm{Bi}_{\mathrm{V}}}+\ln \theta_{\mathrm{o}}\right),
$$

here a is thermal diffusivity in $\mathrm{m}^{2} / \mathrm{s} ; \mathrm{Kn}$ is dimensionless Kondratjev number; $\mathrm{K}$ is Kondratjev form factor in $\mathrm{m}^{2}$; $\tau$ is time in seconds; $\mathrm{k}_{1}$ is $1,2,3$ for plate, cylinder, and spherical like forms correspondently; $\mathrm{Bi}_{\mathrm{V}}$ is generalized dimensionless Biot number; $\theta_{\mathrm{o}}$ is dimensionless temperature.

Calculations provided cooling time for roller 48 minutes 15 seconds.

\section{Low hardenability steel as an example of optimized chemical composition of material}

Low hardenability (LH) steels are widely used in practice. For example, authors [7-11] used the first version of LH steels for manufacturing gears, shafts and bearing rings. The chemical composition of improved version of LH steel is provided in RU Patent № 2158320 [39]: 0.40-0.85 C; $\leq 0.20 \mathrm{Mn} ; \leq 0.20 \mathrm{Si} ; \leq 0.10 \mathrm{Cr} ; \leq 0.10 \mathrm{Ni} ; \leq 0.10 \mathrm{Cu} ; 0.03-0.10 \mathrm{Al} ; 0.06-0.12 \mathrm{Ti} ; \leq 0.40 \mathrm{~V}$. This LH steel was successfully used for manufacturing gears and different kinds of shafts if optimal quenched layer was provided [40, 41].

In 2010, a method for intense quenching of steel, containing $0.15-1.2 \mathrm{C} ; \leq 1.8 \mathrm{Mn} ; \leq 1.8 \mathrm{Si}$; $\leq 1.8 \mathrm{Cr} ; \leq 1.8 \mathrm{Ni} ; \leq 0.5 \mathrm{Mo} ; \leq 1.5 \mathrm{~W} ; \leq 0.007 \mathrm{~B} ; \leq 0.3 \mathrm{Cu} ; 0.03-0.1 \mathrm{Al} ; 0.4 \mathrm{Ti} ; 0.4 \mathrm{~V} ; \leq 0.1 \mathrm{~N} ; \leq 0.4 \mathrm{Zr}$; $0.03 \mathrm{Ca} ; \leq 0.035 \mathrm{~S} ; \leq 0.035 \mathrm{P}$, in condition when HTC exceeds $40,000 \mathrm{~W} / \mathrm{m}^{2} \mathrm{~K}$ was introduced by authors [42]. The equation for determining ideal critical diameter was modified by authors [42] and using nomograms related to cylinders, spheres and plates hardened layer of thickness $(0.1-0.2) \mathrm{D}$ was determined depending on critical diameter DI and size of real steel part. Self-tempering at the temperature $150-300{ }^{\circ} \mathrm{C}$ is provided during performing of this method. The notion has several disadvantages as compared with patented in 2002 in the USA similar intensive steel quenching technology and apparatus [6]. They are:

- heat transfer coefficients (HTCs) more than $40,000 \mathrm{~W} / \mathrm{m}^{2} \mathrm{~K}$ ar e too high for medium and large steel parts and they should be evaluated using criterion (3) with condition (4) which is responsible for establishing direct convection;

- in the equation for DI calculation multiplying factors $f_{n}$ are considered as linear functions of alloy concentrations for all interval up to $1.8 \%$ that creates errors during DI calculations; 
- at present time, tendency in metallurgy is to decrease alloy elements from 2 to 3 times due to possibilities of intensive quenching which creates high compressive residual stresses and provides super-strengthening of material $[6,38]$. There is no sense to waste alloy elements and huge energy;

- authors [42] recommend to perform self-tempering at $150-300{ }^{\circ} \mathrm{C}$ after intensive quenching in condition $\mathrm{HTC}=40,000 \mathrm{~W} / \mathrm{m}^{2} \mathrm{~K}$. However they don't provide interruption time to perform self-tempering. It can be done using Eq. (5). All of this was considered in detail in 2002 in US Patent [6]. Moreover, interruption and self- tempering should be done at optimal bainitic transformations [43];

- thickness $0.1 \mathrm{D}-0.2 \mathrm{D}$ is not optimal quenched layer, especially when using $0.1 \mathrm{D}$. It can be calculated from Eq. (1). Moreover, even in through hardened steels at the surface of machine components the high compressive residual stresses are formed [44-46]. Thickness $0.1 \mathrm{D}-0.2 \mathrm{D}$ will not provide enough strength for hard working machine components;

- the main disadvantage of the elaboration is impossible to use technology for complicated steel parts configurations. It can be used only for cylinders, spheres and plates. Note that regular thermal condition theory of Kondratjev allows operating with any configuration of steel parts [47, 48];

- authors [42] use nomogram for prediction of hardened quench layer in classical forms by observing DI and size, however hardened layer cannot be correct if DI was calculated incorrectly.

In general, alloy elements in existing steels can be radically reduced due to high surface compressive residual stresses and super-strengthening of a material.

\section{Discussion}

At present time, alloy and high alloy steels are quenched in oil and optimal hardenability steels are intensively quenched in water flow or water sprays. LH steels, based on empirical and accurate metallurgical investigations, are suitable for small machine components like gears, shafts, crosses, bearing rings and rollers. LH steels combined with the intensive quenching produce high compressive residual stresses at the surface of steel parts and provide super-strengthening of material that increases their service life. Optimal chemical composition provides optimal quenched layer which in its turn provides optimal residual stress distribution in steel components. The optimal residual stress distribution means high (maximal) compressive residual stresses at the surface of steel parts which smoothly pass to low tensile stresses at their core. Due to soft core, the low tensile stresses cannot create cracks. And also, due to soft core, no swelling is observed in it and as a result the distortion is less. Empirical toleration the chemical composition of steel to size and configuration of machine component or tool takes a long time end is very expensive procedure. That is why in the paper the universal and simple method of chemical and residual stress optimization is developed and discussed. Such approach can be used when hardening irons [49]. The method was many times checked by FEM computer simulation and tested in field condition $[12,25]$. Semi-axles of trucks and bearing rings were many times tested $[25,26]$. The method of calculation can evaluate which steel fits the specific configuration and size of machine component. Based on developed method of calculation, it is possible to compose new grades of steels which can provide optimal residual stress distribution in the given steel component. Due to optimal residual stress distribution and intensive quenching the following benefits are achieved:

- high compressive residual stresses at the surface of steel parts are formed;

- the super strengthening phenomenon in surface layers takes place;

- mechanical properties of material at the core, especially impact strength, are significantly improved;

- crack formation decreases due to compressive residual stresses at the surface and low tensile residual stresses at the core where material is soft;

- distortion of steel parts decreases because core doesn't swell.

A tendency of reducing alloy elements in alloy and high alloy steels is very progressive and promising. 


\section{Conclusions}

1. A similarity correlation concerning depth of hardened surface layer, which was established by author, is a reason for creation of high surface compressive residual stresses and is a basis for optimization of chemical composition of steel.

2. There is an opportunity to reduce all alloy elements in existing steel grades more than two times due to high compressive residual stresses and super-strengthening of material.

3. The similarity correlation allows predicting stress distribution in intensively quenched steel parts after intensive quenching.

4. If chemical composition of LH steel is proper optimized, it can eliminate carburizing processes for variety of large and complicated steel parts and provide the great benefits for industry.

\section{References}

[1] Kobasko, N. I. (2005). Quench Process Optimization for Receiving Super Strong Materials. Proceedings of the 5th WSEAS Int. Conference on simulation, modeling and optimization, 365-372.

[2] Kobasko, N. I. (2005). Quench Process Optimization, Proc. of 6th International Conference "Equipment and Technologies for Heat Treatment of Metals and Alloys. Part I", 88-96.

[3] Kobasko, N. I.; Bozo, S., Heimo, J., Vojteh, L. (Eds.) (2005). The main principles of intensive quenching of tools and dies, Proc. of the 1th International Conference on Heat Treatment and Surface Engineering of Tools and Dies, 39-44.

[4] Grossmann, M. A. (1964). Principles of Heat Treatment. Ohio: American Society for Metals, 302.

[5] Totten, G. E., Bates, C. E., Clinton, N. A. (1993). Handbook of quenchants and quenching technology. ASM international, 513.

[6] Kobasko, N. I. (2002). Patent US 6,364,974 B2. Quenching apparatus and method for hardening steel parts. Assignee: IQ Technologies, Inc. Appl. № 09/551,082. Filed 18.04.2000. Available at: http://patents. com/us-6364974.html

[7] Shepelyakovskii, K. Z. (1972). Strengthening of Machine Components by Induction Surface Hardening. Moscow: Mashinostroenie, 288.

[8] Shepelyakovskii, K. Z., Ushakov, B. K. (1990, December). Induction surface hardening-progressive technology of XX and XXI centuries. In Proc. 7th Int. Congress on Heat treatment and technology of surface coatings, 33-40.

[9] Ouchakov, B., Shepeljakovsky, K. (1998). New Steels and Methods for Induction Hardening of Bearing Rings and Rollers. Bearing Steels: Into the 21st Century, 307-307-14. doi: 10.1520/stp12136s

[10] Shepelyakovswkii, K. Z., Bezmenov, F. V. (1998). New Induction Hardening Technology. Advanced Materials \& Processes, 154 (4), 225-227.

[11] Ushakov, B. K., Efremov, V. N., Kolodjagny, V. V., Skryagin, V. I., Dub, L. G. (1991). New Compositions of Bearing Steels of Controlled Hardenability. Stal', 10, 62-65.

[12] Kobasko, N. I., Morganyuk, V. S. (1983). Study of Thermal and Stress-Strain State at Heat Treatment of Machine Parts. Kyiv: Znanie, 16.

[13] Kobasko, N. I., Morganyuk, V. S. (1985). Numerical Study of Phase Changes, Current and Residual Stresses at Quenching Parts of Complex Configuration. Proceedings of the 4th International Congress of Heat Treatment Materials, 465-486.

[14] Kobasko, N. (2010). Intensive Steel Quenching Methods. Quenching Theory and Technology Second Edition. CRC Press, 510-568. doi: 10.1201/9781420009163-c15

[15] Morhuniuk, W. S., Ushakov, B. K., Kobasko, N. I. (2004). Design of Steel-Intensive Quench Processes. Handbook of Metallurgical Process Design. CRC Press, 733-764. doi: 10.1201/9780203970928.ch17

[16] Kobasko, N. I., Morganyuk, V. S., Dobrivecher, V. V. (2002). Control of Residual Stress Formation and Steel Deformation During Rapid Heating and Cooling. Handbook of Residual Stress and Deformation of Steel. Materials Park: ASM International, 312-330.

[17] Liscic, B., Tensi, H., Canale, L., Totten, G. (Eds.) (2010). Quenching Theory and Technology, Second Edition. CRC Press, 725. doi: 10.1201/9781420009163

[18] Xie, L., Funatani, K., Totten, G. (Eds.) (2004). Handbook of Metallurgical Process Design. CRC Press, 957. doi: 10.1201/9780203970928 
[19] Neklyudov, I. M., Shulayev, V. M. (2005). Equipment and Technologies for Heat Treatment of Metals and Alloys. Proc. of 6th International Conference, 295.

[20] Sahay, S. S., Sarmiento, G. S. (Eds.) (2013). Special Issue on Thermal Process Modeling, Simulation and Optimization. ASTM International, W. Conshohocken, 459.

[21] Mastorakis, N., Mladenov, V., Bojkovic, Z. (Eds.) (2010). New Aspects of Fluid Mechanics, Heat Transfer \& Environment. WSEAS Press, 385.

[22] Kobasko, N. (2012). Steels of optimal chemical composition combined with intensive quenching. International Heat Treatment and Surface Engineering, 6 (4), 153-159. doi: 10.1179/1749514 $812 \mathrm{z} .00000000032$

[23] Kobasko, N. I. (2011). Correlation Between Chemical Composition of Steel, Optimal Hardened Layer, and Optimal Residual Stress Distribution. Film and Nucleate Boiling Processes, 81-102. doi: 10.1520/ stp153420120005

[24] Kobasko, N. I. (2008). The steel superstrengthening phenomenon, part 2. International Journal of Microstructure and Materials Properties, 3 (4/5), 526-547. doi: 10.1504/ijmmp.2008.022034

[25] Kobasko, N. I. (1980). Steel Quenching in Liquid Media under Pressure. Kyiv: Naukova Dumka, 206.

[26] Liscic, B., Tensi, H. M., Luty, W. (Eds.) (1992). Theory and Technology of Quenching. Springer-Verlag Berlin Heidelberg, 484. doi:10.1007/978-3-662-01596-4

[27] Kim, T., Kobasko, N. I., Liu, Y., Nayar, A. (2006). Worldwide Guide to Equivalent Irons and Steels. Materials Park: ASM International, 1387.

[28] Dossett, J. L., Totten, G. E. (Eds.) (2013). Steel Heat Treating Fundamentals and Processes Vol. 4A. Materials Park: ASM International, 768.

[29] Powell, J. A. (2013). Basics of IQ Process, Presentation at Intensive Quenching Workshop, Cleveland, Ohio, USA.

[30] Kobasko, N. I. (2016). Improvement of IQ-3 processes to eliminate crack formation, decrease distortion, and maximize material strength, and ductility. Eureka: Physics and Engineering, 4, 3-10. doi: 10.21303/2461-4262.2016.000122

[31] Yu, W. (Ed.) (2009). Recent Advances in Intelligent Control Systems. London: Springer, 374. doi: 10.1007/978-1-84882-548-2

[32] Mastorakis, N., Demiralp, M., Mladenov, V. M., Zemliak, A. et al. (2011). Computers and Simulation in Modern Science. WSEAS Press, 238. tional, 498

[33] Totten, G. E. (Ed.) (2002). Handbook of residual stress and deformation of steel. ASM interna-

[34] Totten, G. E. (2006). Steel Heat Treatment Handbook, Second Edition. CRC Press, 1077.

[35] Ravnik, F., Grum, J. (2011). Heat Transfer Stages Recognition by Boiling Acoustic During Quenching. Journal of ASTM International, 8 (1), 103386. doi: 10.1520/jai103386

[36] Grum, J., Bozic, S. (2003). Acoustic emission during quenching of 42 CrMo 4 steel. In 4 th International Conference on Quenching and Control of Distortion, 267-272.

[37] Kichigin, A. M., Kobasko, N. I., Povsten, S. G., Tyltin, A. A., Timchenko, N. P. (1990). Patent 4605186/31-02. Method for Control of Steel Parts Heat Treatment. Assignee: Bayer Materialscience Ag. Appl. № 621.785.79(088.8). Filed 14.11.1988. Available at: http://www.findpatent.ru/patent/159/1595928.html

[38] Kobasko, N., Aronov, M., Powell, J., Totten, G. (2010). Intensive Quenching Systems: Engineering and Design. ASTM International, 242. doi: 10.1520/mnl64-eb

[39] Shepeliakovskii, K. Z., Lobozov, V. P., Kuznetsov, A. A., Nikitin, S. I., Kamenskih, A. A., Karpov, A. A., Zelenov, V. N., Ezubchenko, V. N. (2000). Patent RF 2158320. Konstruktsionnaia STAL ponizhennoi prokalivaemosti. Assignee OAO “Chusovskoi metallurgicheskii zavod”. Appl. № 99125102/02. Filed 29.11.1999. Available at: http://ru-patent.info/21/55-59/2158320.html

[40] Kobasko, N. I. (2010). Energy Efficient and Eco-friendly Intensively Quenched Limited Hardenability Low Alloy Steels. Advances in the State of the Art of Fire Testing, 644-644-18. doi: 10.1520/stp49177s

[41] Kobasko, N. (2007). Limited - Hardenability Steels and New Heat Treating Technologies. Material Science \& Technology 2007 Conference and Exhibition (MS\&T’07), 471-480.

[42] Munnig, J., Pennemann, B., Rausch, A. K. (2012). Patent RU 2450060. Method of thermal treatment of parts from structural steel of lower and regulated hardenability. Assignee: Scientific 
and Production Company Technology Engineering and Space-surface hardening. Appl. 2010154543/02. B 13. Filed 31.12.2010.

[43] Bhadeshia, H. K. D. H. (2015). Bainite in Steels: Theory and Practice. 3rd edition. Money Publishing, 616 .

[44] Rath, J., Lübben, T., Hunkel, M., Hoffmann, F., Zoch, H. W. (2009). Grundlegende Untersuchungen zur Erzeugung von Druckeigenspannungen durch Hochgeschwindigkeits-Abschrecken. HTM Journal of Heat Treatment and Materials, 64 (6), 338-350. doi: 10.3139/105.110037

[45] Rath, J., Lubben, T., Hoffmann, F., Zoch, H. W. (2010). Generation of compressive residual stresses by high speed water quenching. International Heat Treatment and Surface Engineering, 4 (4), 156-159. doi: 10.1179/174951410x12851626812970

[46] Zoch, H. W., Schneider, R., Luebben, T. (2014). Proc. of European Conference on Heat Treatment and 21st IFHTSE Congress. Munich (Germany), 566.

[47] Kondratjev, G. M. (1957). Teplovye Izmereniya [Thermal Measurements]. Moscow: Mashgiz, 8.

[48] Lykov, A. V. (1967). Teoriya Teploprovodnosti [Theory of Heat Conductivity]. Moscow: Vysshaya Shkola, 600 .

[49] Aronov, A., Kobasko, N. I., Powell, J., Kim, H., O’Rourke, B., Andreski, B. (2015). Application of Intensive Quenching Process for Steel Mill Rolls Made of Ductile Iron. The MS\&T, Material Science \& Technology Conference and Exhibition, 4-8. 